\title{
Mental Health, Religion and Suicide
}

\author{
Ishaq Ibrahim Hajiyousouf, Sefa Bulut \\ Department of Counseling Psychology, Ibn Haldun University, Istanbul, Turkey \\ Email: sefabulut22@gmail.com
}

How to cite this paper: Hajiyousouf, I.I. and Bulut, S. (2022) Mental Health, Religion and Suicide. Open Journal of Medical Psychology, 11, 12-27. https://doi.org/10.4236/ojmp.2022.111002

Received: September 14, 2021

Accepted: January 2, 2022

Published: January 5, 2022

Copyright (c) 2022 by author(s) and Scientific Research Publishing Inc. This work is licensed under the Creative Commons Attribution International License (CC BY 4.0).

http://creativecommons.org/licenses/by/4.0/

\begin{abstract}
Suicide is one of the most common yet serious concerns, and a worldwide subject that individuals have debated from the past to the present. Suicidal ideation affects and disrupts the functionality of a human being regardless of age, gender, ethnicity, or even religion. This article aims to discuss suicide in general and from an Islamic perspective in specific, as research has shown that an Islamically oriented approach and intervention works better with the Muslim population in general. The paper also aims to have a broader view of how Islam categorized suicide classically and its modern implications, which also lets us explore the similarities, and differences between the Islamic perspective and different religions about suicide and related mental health concerns. A collection of both classic and modern sources was used to extract information and provide a scope of definitions to clarify suicide and religiosity concerning the teachings and opinion of Islam about the meaning of life, afterlife, and soul. It was found that the Muslim population showed a lower rate of suicide in comparison to individuals from other religions, and religious individuals showed faster recovery from suicidal ideation. Yet, Muslims are not immune to mental health conditions that would result in suicide. Therefore, further studies and research need to be conducted to understand the huge stigma around Muslim about mental health and suicide in the Muslim communities, to compare the effectiveness among the religious and the non-religious Muslims, and lastly to fill the gap as to why the Muslim population tends to be hesitant in seeking help regarding their psychological problems.
\end{abstract}

\section{Keywords}

Suicide, Mental Health, Religion, Suicide Attempt

\section{Religion, Mental Health, and Suicide}

Suicide by itself is not considered an illness. It is a worldwide phenomenon that individuals have struggled with from the past to the present, as it has been a top- 
ic for centuries which was discussed by historians, theologians, and philosophers. Since the ancient Greece and Rome, it was debated whether it is morally acceptable to end one's life or not. Then it was considered as an unacceptable attitude by the Christian Europe, as it was seen as an act of arrogant refusal to submit to God's will. Therefore, it was considered as a crime, also such acts were deemed, and the bodies of the suicide completers were often desecrated, and their possessions confiscated. Then in the $19^{\text {th }}$ century it became a concern that got the attention of psychiatrists and sociologists [1]. Suicide can be explained as a behavior, which may include ending one's life, or just a kind of attempt that may not lead to death. In our modern time, suicide has become an important public health problem, since the number of individuals committing suicide is increasing day after day, therefore, the necessity of increasing the awareness internationally has become the major factor for prevention of such actions [2].

It is noted that regardless of the faith, even individuals from traditional, conservative, or religious societies that condemn the act of suicide, may also go through suicidal thoughts to end their problems and sufferings, just as likely as those from non-religious societies. However, individuals from religious and conservative societies would be less likely to have suicidal behavior and they may not reach to acting upon their suicidal thoughts, since suicide is condemned and doomed in their religion and is morally forbidden [3].

Although, suggesting that religiosity or religious affiliation is a protective factor against suicidal ideation is complicated, yet [4] stated that it may hinder the suicide attempts, however it is advised to take other variables into consideration, such as culture in specific communities and its implications upon individuals. The religiously committed individual may not see suicide as an option [5]. And regardless of what the religion is, [6] also noted that the protective influence of religious groups affects the community as a whole and not just members of particular religious affiliations. In addition to the protective effect of religious affiliation, researchers have found that religious beliefs may also be protective, such as having a belief in the afterlife, for instance, a person who suffers may endure adversity without becoming hopeless, which is a prime risk factor for suicide [7].

It is also has been stated in several studies that religions have a relationship and play major roles in reducing suicide attempts. Also, it has been well-documented that religious countries have lower suicide rates in comparison to secular ones [8]. In particular, people residing in nations with relatively high levels of religiosity, associated with one of the four major faiths such as Buddhism, Christianity, Hinduism, and Islam, are found to have shown lower rates of acceptability of suicide [5]. Additionally, [9] stated that higher levels of religiosity across these major denominations have historically been associated with decreased suicide risk.

Mental health is an essential component of the Islamic tradition and history. Yet, mental health is very stigmatized as a topic in Muslim societies. Muslims are not immune to mental health conditions including suicide ideation and thoughts. But essentially it is suicide that is stigmatized most. In Islam, human life is 
respected and to be protected and Islam prohibits people from killing themselves. Despite that, the reality is that many Muslims globally struggle with thoughts and ideations of killing themselves, and many Muslims do die by suicide. Furthermore, faith and prayer alone cannot stop a Muslim from feeling depression, thoughts of self-harm, or suicide. That is why suicide is tragic and whensoever it occurs in the Muslim community, we must respond in a manner that is therapeutic and grounded in Islamic principles.

In the Islamic teachings, it is highlighted that human beings, sons of Adam were created by the creator Allah s.w.t for a divine purpose and that humans were honored by several blessings and one of them is that they were given a position that is higher than the other creations, as it was mentioned in the noble Quran "Indeed, We have dignified the children of Adam, carried them on land and sea, granted them good and lawful provisions, and privileged them far above many of Our creatures" (17:70) [10]. The divine purpose is to worship and to be a successor on earth as it was mentioned in the Quran "Remember when your Lord said to the angels", "I am going to place a successive 'human' authority on earth." They asked "Allah", "Will You place in it someone who will spread corruption there and shed blood while we glorify Your praises and proclaim Your holiness?" Allah responded, "I know what you do not know." (02:30) [10].

Islam has also given an emphasis and importance on respecting the soul and considered it as precious and valued, since it is one of the blessings human beings were bestowed with, and they were ordered by the almighty to preserve and protect it. In the meantime, they were also forbidden from any means of violating the soul by keeping it alive and avoid killing oneself or even others, since the soul is given by God as Amanah or trust, then people should be trustworthy in keeping that trust. Therefore, protecting life is in fact an obligation in Islam, it is also stated that taking life is like killing the whole of mankind, however, saving a life is like saving the whole of mankind. As it was also mentioned in the Holy Quran "That is why We ordained for the Children of Israel that whoever takes a life unless as a punishment for murder or mischief in the land it will be as if they killed all of humanity; and whoever saves a life, it will be as if they saved all of humanity." (5:32) [10].

In fact, Islam is guided by the verses that mention the importance of the soul and condemns suicide: "Nor take life which God has made sacred, except for just cause" (17:33) [10] Also, it is mentioned in the Quran that choosing to end a life is prohibited as God is the decider of all. Life is given by God to each person for a purpose and we are here on earth to fulfill that purpose. We are therefore not free to decide when our purpose is finished and when we should die. If we take or attempt to take our own life, we are trying to perform a function that belongs to God. The Quran states: "Nor kill nor destroy yourselves, for surely God has been to you Most Merciful." (4:29) [10]. And “Although Our messengers already came to them with clear proofs, many of them still transgressed afterward through the land." (05:32) [10]. 
Islam promotes harmony and believes in a balance or a golden mean. That is why it preaches harmony and encourages finding solutions to worldly problems rather than relying just upon the promise of the afterlife. It is mentioned in the Quran "Seek the life to come by means of what God granted you, but do not neglect your rightful share in this world. Do good to others as God has done good to you. Do not seek to spread corruption in the land, for God does not love those who do this" (28:77) [10].

Islam is the religion followed by more than 1.6 billion Muslims globally and it provides them with ethics, values, and a behavioral code which can be highly beneficial in developing healthy coping mechanisms and adaptive strategies to deal with stressful and hard life events. Islam promotes harmony and believes in a balance or a golden mean. That is why it preaches harmony and encourages finding solutions to worldly problems rather than relying just upon the promise of the afterlife.

Furthermore, Ibn Abbas reported that the Messenger of Allah, peace, and blessings be upon him, said, "Take advantage of five before five: your youth before your old age, your health before your illness, your riches before your poverty, your free time before your work, and your life before your death." [11] Taking advantage of life could refer to maintaining well-being and high good mental health because in their absence a person cannot totally realize and fulfill his or her potential. That is why maintaining a good state of mental well-being can also be considered as an act of Ibadah or worship.

Even [12] stated and confirmed that there are several factors leading to the risk of suicide and suicide attempts, those factors can be social and family risk factors, individual and personality factors, mental health factors, hastening circumstances, traumatic life events, environmental and contextual factors. In addition, as we could understand from the previous statement suicide can be influenced by cultural, religious, historical, philosophical, socioeconomic, and even traditional factors.

Although committing suicide might be directly influenced by many factors, such as personal cultural background, biological, social or even environmental causes, as [13] mentioned that the most common factor which causes individuals to end their lives is depression and is considered as the leading cause among many psychiatric disorders, besides that it is stated that income does not have a relationship with a high or low rate of suicide, since it is found that even among individuals who are in high-income countries, the most common cause of death for half of them is suicide.

However, [14] stated that suicide rates become greater when the mental health is neglected, specifically in areas under conflict, war zone, or even in refugee camps. Mental illnesses such as depression, anxiety, and post-traumatic stress disorder are most likely to increase among children and adults who are affected by the trauma of conflicts and displacement, limited access to water, shelter, extreme hot or cold weather and challenges such as unemployment and burden of immigration, leading the mental health to be neglected, which as a result be- 
comes a direct cause of greater suicide risks.

Suicide is generally defined as death caused by harming oneself with the willingness to die. A suicide attempt can be explained when someone harms themselves with any intent to end their life, but not necessarily die as the result of their actions. Suicidal behaviors include thinking, planning, taking actions, and ending one's own life generates a serious public health concern.

However, the terminology of suicide was categorized and clarified with various detailed definitions by [2] such as the term suicide was defined by a fatal self-injurious act with some evidence of intention to die. Another term is suicide attempt which is explained by a potentially self-injurious behavior associated with at least some intent to die.

In addition, an active suicide ideation was also defined by thoughts about taking action to end one's life, including identifying a method, having a plan, or having an intent to act. Moreover, [2] also added the term passive suicide ideation, which is the thought about death or wanting to be dead without any plan or intentions. The fifth term was categorized by non-suicidal self-injury or self-injurious behavior with no intent to die. Furthermore, one of the terminologies is suicidal events, which is explained by the onset or worsening of suicide ideation or a suicide attempt, an emergency referral for ideation, or suicidal behavior. Lastly, preparatory acts towards imminent suicidal behaviors and deliberate self-harm which is any type of self-injurious behavior, including suicide attempts and non-suicidal self-injury.

Furthermore, [15] also highlighted in their study that important religious differences regarding suicidal attempts, suicidal ideation, and attitude towards suicide among the general population, showed that suicidal thoughts and suicidal behaviors were comparatively low among Muslim participants than Hindus. Further, their study revealed more negative attitudes were prevalent among Muslims towards suicide and suicidal behavior. For instance, [16] also added that one factor of a lower rate of suicidality in Islam is that Suicide may be seen as an unforgivable sin, and many Muslims are fearful of the consequences of suicidal behavior.

In addition, [17] stated that protective factors have more often been identified in research on suicidality and Islam, specifically intrinsic religiousness within Islam has been demonstrated to be a protective role against suicide attempts. Moreover, it seems that Islamic countries throughout the world display lower suicide rates compared to the other countries either developed or developing. However, as has been mentioned, most studies dealing with the relationships between Islam and suicide have focused descriptively on the extent of the problem and not the underlying mechanisms [18].

Obviously, religions are beneficial as they are identified to be protective factors against suicide. [19] have observed that suicide rates are higher in countries where religious beliefs are not actively promoted by the state and lower in countries where they are and confirm that there are various instruments by which re- 
ligion may be protective against suicide, since the idea that religion is a major integrating, solid force in traditional societies, and have argued that that force is specifically protective against suicide.

In addition, it is found that spiritual commitment and having a regular connection to God and religion, may be helpful in the well-being of individuals, and it may help also in providing meaning in life. For instance, [20] have stated that in a longitudinal study of approximately 90,000 participants, that weekly attendance at religious services lowers suicide risk five times in comparison with no attendance at services at all.

\section{Risk Factors}

Risk factors can be defined as the conditions that increase an individual's vulnerability to act upon suicidal thoughts. Knowledge and awareness of the risk factors is essential to act in time and help people who are at greater risk to act upon their suicidal tendencies and thoughts. Greater awareness also helps in intervening on time by referring a person for professional help in time. Some of such risk factors include:

1) Previous suicide attempts: Individuals with a record of previous suicide attempts and self-harm are more likely to involve again in suicidal behaviors [21].

2) Exposure to other people's suicidal behavior: This can include individuals in the family, friends, celebrities, or movies or television shows [22].

3) Access to lethal supplies: This can include tablets, substances such as alcohol or drugs, guns, risky objects, etc. An access to these materials may make it easier to attempt suicide [23].

4) Substance dependence or abuse: That is because when a person is experiencing withdrawal or in the state of intoxication, they are more likely to indulge in impulsive behavior and less likely to ask for help which can make it more likely to attempt suicide [24].

5) The existence of a mental health condition: Persons suffering from depression, bipolar disorder, borderline personality disorder, schizophrenia and substance abuse are at greater risk for attempting suicide [21].

6) Social isolation: According to [25] individuals who have difficulty in starting, developing, and maintaining fulfilling meaningful close relationships can experience greater loneliness which can result in greater susceptibility to suicide.

7) Low self-esteem: People with low self-esteem generally have negative self-beliefs and how others perceive them. Such an inaccurate perception could contribute towards the thoughts of suicide [26].

8) Exhibiting impulsive or aggressive behavior: Such behaviors are highly correlated with suicidal behaviors as reduced ability to think about the consequences of one's actions could make it easier to attempt suicide [21] [27] \& [28]

9) Chronic pain or physical illness: Some medications can have huge effects 
on mood and impulse control. Chronic pain could contribute to feelings of depression, anxiety, and helplessness which consequently can increase the likelihood of suicide [28].

10) Presence of abuse and/or violence: Experiences like physical, domestic, emotional, sexual violence and abuse can also contribute to attempted suicide ([21] \& [29]).

11) Long-term or recent stressors: This could include financial and relationship issues, legal problems, harassment or and other social issues [30].

\section{Protective Factors}

Protective factors are those that mitigate the risk factors and eventually reduce the likelihood of a person carrying out a suicide attempt. Protective factors are the key in reducing vulnerabilities and offset risk factors. As psychologists, we must care about the well-being of our community which is why fostering and cultivating protective factors within a community and in an individual can assist in reducing the risk of suicide. Some of the protective factors include:

1) Social connectedness: When a person has good and healthy social connections like one's family, friends, or community that one holds dear, it is a source of support, and such an individual less likely wants to commit suicide [31].

2) Religious beliefs that discourage suicide: Individuals who morally object to suicide due to religious norms and beliefs are less likely to attempt suicide [32].

3) Responsibility towards others: People who have a sense of responsibility towards others like one's family, children or pets have a greater reason to live, that in turn reduces the probability of attempting suicide [33].

4) A positive sense of self-worth: An individual with positive sense of contribution is more likely to have a sense of self-acceptance, self-respect, and satisfaction with oneself and life. Such qualities help a person overcome negative thoughts about self and one's future, which leads to decreasing the likelihood of acting upon suicidal thoughts [27].

5) Motivation for the future: People who have a sense of direction and future dreams and goals to work towards are more likely to persevere through hardships and less likely to end their lives [34].

6) Impulse control: This enables an individual to think through effects of one's actions and decreases the likelihood of attempting to end one's life [21].

7) Good help-seeking, problem-solving, and coping skills: A person that is able to seek support or use skills to successfully address problems, emotional troubles, and hurt is less likely to attempt suicide [35].

\section{Warning Signs}

Recognizing warning signs is key to helping someone who has suicidal thoughts. Some of the warning signs of suicide include:

1) Talk about ending their life. Some individuals may speak openly about 
wanting to end their life, while others may speak indirectly about suicide by stating they no longer have a reason to live.

2) Putting affairs in order. They may give away possessions and make final calls to say goodbye as they prepare for their death.

3) Isolate from family and friends. Individuals may pull away from loved ones or intentionally push them away, wanting to be alone. Their actions may be due to many reasons: feeling hurt by loved ones, feeling no one genuinely cares for them, or feel they do not belong.

4) Express negative thoughts or feelings. Individuals may report unbearable pain, feeling of hopelessness, being trapped, and inability to continue living. They may see themselves as damaged, a burden on others or feel rage and anger at their condition and believe it will never change or get better.

5) Stops taking care of themselves. An individual may stop practicing good hygiene, caring how they dress, as well as a noticeable change in appetite (no eating or overeating).

6) Loss of interest. An individual may lose the ability to enjoy things in life, resulting in withdrawal from activities they used to enjoy.

7) Dangerous/risky behavior. Individuals may engage in reckless driving, use of drugs and alcohol, as well as unsafe sex because he or she may no longer value their life and seek to end it.

8) Sleep changes. An individual may be sleeping too much, too little, or constantly waking up from sleep.

\section{Religion and Prevention of Suicide}

Suicide is a serious public health concern. It is the cause of approximately one million lost lives every year, and it is listed among the first three causes of death worldwide, nations around the world have shown concerns regarding tackling and reducing this issue, and work hand in hand to reach to successful applicable preventive methods, strategies, and guidelines for the past decades. According to [36], the UN with cooperation from experts in WHO have published a report titled with "Prevention of Suicide: Guidelines for the formulation and implementation of national strategies" that contains several guidelines that put stress on identifying key elements that causes suicide, and approaches on how to prevent them effectively through studied strategies.

In fact, it is unacceptable to neglect or abandon the fact that religion has no effect in preventing suicide attempts. Taking religion into account is important, and may actually help to prevent it, ideas such as religious commitment and core beliefs may play a role and be in use as a tool to encounter with or tackle against suicide, since faith gives people meaning in life, and reminds them that there is a reward and punishment since religions are basically to provide comfort to the believers, and provide them with strength to endure the pain of adversities of life as long as they believe in the afterlife [8].

Faith, in general, is thought to be one of the most important protective factors 
in reducing suicide, religion is an underestimated factor. Religiosity plays an essential role in reducing depression, negative thoughts, stress, and even negative emotions such as anger and frustration. Spirituality has also shown to be an effective method of decreasing the risk of development of major psychological disorders such as major depression and anxiety and is a helpful tool to decrease suicidal ideation and behavior since it enables and empowers the individuals to cope up with their suffering and difficulties of negative life circumstances [37].

In addition, [38] have added and supported the conclusion that some elements such as religious involvement are certainly associated with lesser depression. They have mentioned that individuals who are regularly involved in religious group activities and who highly value faith for fundamental reasons may be at lower risk of becoming depressed. Moreover, even for those people who experience depression, studies suggest that they recover more rapidly from it than those who are not religious. In a study conducted by [39] confirmed that religious individuals who attend prayers regularly have shown less vulnerability against psychological problems and shown faster recovery from depression.

Moreover, [40] have found that the protective factor of religiosity may also be differentiated when it comes to age range, it is suggested that religion may play as protective tool against suicide in older adults more than young adults, although the older adults may seem to be having suicidal ideations but that might be referred to having reduced fear of death in general in the late stages of life. However, in a study conducted regarding the association between religion and suicidality among older adults aging more than 59, [41] confirmed that the older adults who are attending the church on regular basis, may show less suicidal ideation.

In the Islamic teachings, for instance, a believer is not only requested to be physically strong but also is obligated to have psychological strength, Islam went into teaching the Muslims the manners of having a proper living style and ethics, and encouraged them to hold their negative emotions and become patient and be as resilient as possible, for instance, regarding an emotion such as anger that was mentioned in sayings of the prophet Mohammed peace be upon him when he was asked for a piece of advice and he said, "There is nothing swallowed with a greater reward from Allah than a servant who swallows his rage, seeking thereby the countenance of Allah." [42] and in another event, the companion of the prophet Abdullah ibn Mas'ud reported: The Messenger of Allah, peace, and blessings be upon him asked, "Whom do you consider to be a fighter among you?" We said, "One whom men cannot wrestle down." The Prophet said, "It is not so. Rather, it is one who controls himself when angry" [43]. This explains how important it is to focus on the small details that are relevant to the concept of mental health and strength, which may help in preventing harmful actions, which may cause bigger impacts and negative results.

In another Hadith, Abu Huraira reported that: The Messenger of Allah, peace, and blessings be upon him, said, "The strong believer is more beloved to Allah 
than the weak believer, but there is goodness in both. Be eager for what benefits you, seek help from Allah, and do not be frustrated. If something befalls you, then do not say. If only I had done something else. Rather say. Allah has decreed what he wills. Verily, the phrase 'if only' opens the way for the work of Satan." [43]. Again, this is a clear instruction by the prophet peace be upon him to keep ourselves away from hopelessness and to be resilient against serious events of calamities, and to put our full trust in God the creator.

Even though it may not be true that suicide rate is low in the Muslim societies, yet some studies have shown that Muslim communities in Africa have indicated that lower numbers for individuals committing suicide, especial when compared with Christian communities. This may be because of the Islamic strict laws, teachings, and disapproval of suicide, since generally Islam considers the soul as a sacred trust from God, and people have no free-will to give decisions to end their lives [44].

It is also important to mention that since suicide is strictly disapproved in Islam, survivors of suicide attempts and their families in Muslim communities usually become stigmatized and outcasted, and because Sharia (Islamic Law) considers suicide and or suicide attempts as criminal offences, Muslim societies have a hostile view regarding such actions. Therefore, survivors of suicide attempt will be facing more problems, such as feeling of guilt, sadness, depression, anger, and shame [45].

On the other hand, Islam has instructed believers not to only have positivity but also has instructed them to be aware of negativity, hopelessness, pessimism, and despair because they may be the cause of losing mental health and well-being. For instance, it is reported that the prophet peace be upon him used to despise pessimism and whatever notion that leads to negative thinking because it goes against the belief in destiny, Abu Huraira reported that the Prophet, peace, and blessings be upon him, said, "There are no omens, but the best of it is optimism.” They said, "O Messenger of Allah, what is optimism?" The Prophet said, "A righteous word one of you hears" [46]. In another narrative, Abu Huraira also reported that the Messenger of Allah, peace, and blessings be upon him, said, "Verily, when Allah Almighty bestows bounties upon a servant, He loves to see the traces of His bounties upon him. He dislikes one who wallows in misery and pessimism. Allah hates the obstinate questioner, and He loves those who are modest, chaste, and sober." [47].

Religion allows individuals to change their pre-learned beliefs and goals that were disrupted and bring them to an understanding that is more harmonized with their thoughts of the way they are experiencing in life. Therefore, religion is useful and effective means to help people reach a better and positive change during or after cases of experiencing stressful events. [48] suggests that religions in general helps people in finding meaning out of the incidents or experiences they have in their lives, especially on those challenging, painful, or incredibly stressful occasions. By means of religion, people tend to understand their surroundings and draw a meaningful inference that makes them feel less stressed or 
in a better state.

In the Islamic perspective, committing suicide is considered as a grave sin, and Muslims are clearly instructed in several verses in the Holy Quran to avoid killing one another or killing one's self, for example, Muslims were told to protect their souls, and not end it since it is given by the creator and it shall be taken by Him, it is not in the hands of people to decide such things or take such actions, as mentioned in the Quran "O believers! Do not devour one another's wealth illegally, but rather trade by mutual consent. And do not kill each other or yourselves. Surely Allah is ever Merciful to you." (4:29) [10]. Moreover, [49] mentioned the reasons that individuals may be classified in several parts such as, losing faith and having despair in God's mercy, weak religiosity, losing trust in the creator, having no capacity to accept or tolerate difficulties, troubles, or sufferings, committing sinful acts, and not accepting fate and destiny.

According to the study of [50] which was conducted to investigate the influence of religion on population attitudes towards suicide, they found out that the suicidal attempts appeared to be higher in Hindu population than Muslim population, and the Hindu population showed acceptance towards suicide. However, Muslims were less likely to accept suicide, and mentioned that even though Muslims are showing acceptancy in discussing such topics or subjects, yet individuals from Muslim society and approximately half of them confirmed that people who speak about suicide would not commit suicide and that this negative attitude may be due to being unaware of the nature of suicide [51].

On the contrary, having said that Muslims may have lower rates of suicide does not indicate that the numbers are not something that does not require concern or attention, dying by suicide is a public concern regardless of religion, ethnicity, or age range. Yet understanding the reasons that led Muslims to have suicidal ideation are also important to solve this reoccurring problem. According to [52] [53], and [54] the Muslims who reported having attempted suicide did so due to:

- Mental health condition.

- Substance abuse.

- Financial problem.

- Domestic violence.

- History of abuse.

- Difficult family environment/expectations.

- Culture conflict.

- Lack of connectedness or affection.

- Lack of self-worth.

\section{Conclusions}

Even though, it was found that the Muslim population showed a low rate of suicide in comparison to individuals from other religions, and religious individuals showed faster recovery from suicidal ideation, and religious affiliation may 
hinder the suicide attempts, yet Muslims are not immune to mental health conditions. Our beloved ones, friends, family, and community members struggle silently on daily basis with suicidal thoughts and ideas. They too deserve our love, care, and attention. The huge stigma around the Muslim mental health and suicide especially has prevented much needed research in this area like the prevalence of suicide in the Muslim communities. That is why the global research has found discrepant rates when it comes to Muslim reported suicides, which could be a result of underreporting [55] [56].

Therefore, further studies and research need to be conducted to understand the huge stigma around Muslim mental health and suicide in the Muslim communities, to compare the effectiveness among the religious and the non-religious Muslims, how to increase the awareness regarding suicide, and lastly how to fill the gap as to why the Muslim population tends to be hesitant in seeking help regarding their psychological problems.

It is also important to provide skilled care providers who understand certain religious communities or individuals who are religiously affiliated, to provide the right and necessary psychological support for help seekers, especially for those who are experiencing suicidal ideations or those who are planning to commit suicide because of feeling of loneliness and helplessness to easily get the necessary help they need and receive instructions or psychological support. It is also recommended to ensure the best mental and physical health of certain religious community members. The Quran mentions:

"Whereby Allah guides those who seek His good pleasure to paths of peace and safety. He brings them out of darkness unto light by His decree and guides them unto a straight path." (Quran, 05:16) [10].

\section{Conflicts of Interest}

The authors declare no conflicts of interest regarding the publication of this paper.

\section{References}

[1] Eghigian, G. (2018) A "Sickness of Our Time": How Suicide First Became a Research Question. Psychiatric Times, 35, 11-13.

https://www.psychiatrictimes.com/view/sickness-our-time-how-suicide-first-becam e-research-question

[2] Turecki, G., Brent, D.A., Gunnell, D., O’Connor, R.C., Oquendo, M.A., Pirkis, J. and Stanley, B.H. (2019) Suicide and Suicide Risk. Nature Reviews Disease Primers, 5, 1-22. https://doi.org/10.1038/s41572-019-0121-0

[3] Kamal, Z. and Loewenthal, K.M. (2010) Suicide Beliefs and Behaviour among Young Muslims and Hindus in the UK. Mental Health, Religion \& Culture, 5, 111-118. https://doi.org/10.1080/13674670210141052

[4] Lawrence, R.E., Oquendo, M.A. and Stanley, B. (2015) Religion and Suicide Risk: A Systematic Review. Archives of Suicide Research, 20, 1-19. https://doi.org/10.1080/13811118.2015.1004494

[5] Stack, S. and Kposowa, A.J. (2011) Religion and Suicide Acceptability: A Cross-National 
Analysis. Journal for the Scientific Study of Religion, 50, 289-306. https://doi.org/10.1111/j.1468-5906.2011.01568.x

[6] Tubergen, F.V. (2005) Denomination, Religious Context, and Suicide: Neo-Durkheimian Multilevel Explanations Tested with Individual and Contextual Data. American Journal of Sociology, 111, 797-823. https://doi.org/10.1086/497307

[7] Eskin, M. (2004) The Effects of Religious versus Secular Education on Suicide Ideation and Suicidal Attitudes in Adolescents in Turkey. Social Psychiatry and Psychiatric Epidemiology, 39, 536-542. https://doi.org/10.1007/s00127-004-0769-x

[8] Stack, S. (1983) The Effect of Religious Commitment on Suicide: A Cross-National Analysis. Journal of Health and Social Behavior, 24, 362-374.

https://doi.org/10.2307/2136402

[9] Rasic, D., Robinson, J.A., Bolton, J., Bienvenu, O.J. and Sareen, J. (2011) Longitudinal Relationships of Religious Worship Attendance and Spirituality with Major Depression, Anxiety Disorders, and Suicidal Ideation and Attempts: Findings from the Baltimore Epidemiologic Catchment Area Study. Journal of Psychiatric Research, 45, 848-854. https://doi.org/10.1016/j.jpsychires.2010.11.014

[10] The Nobel Qur'an (1984) Translation of the Meanings of the Noble Qur'an in the English Language. AI-Hilali, M.T.-u.-D. and Khan, M.M., Trans., King Fahd Complex for the Printing of the Holy Qur'an, Madinah.

[11] Al-Albani, M.N.-D. (2000) Sahih At-Targheeb wa-Tarheeb by Al-Mundhiri. In Sahih At-Targheeb wa-Tarheeb by Al-Mundhiri, Almaaref Publication Library, Riyadh, 3355.

[12] Beautrais, A.L. (2000) Risk Factors for Suicide and Attempted Suicide among Young People. Australian and New Zealand Journal of Psychiatry, 34, 420-436. https://doi.org/10.1080/j.1440-1614.2000.00691.x

[13] Ahmed, H., Hossain, M.D., Aftab, A., Soron, T.R., Alam, M.T., Alam, M. and Aftab, U. (2017) Suicide and Depression in the World Health Organization South-East Asia Region: A Systematic Review. WHO South-East Asia Journal of Public Health, 6, 60-66. https://doi.org/10.4103/2224-3151.206167

[14] Carletona, T.A. (2017) Crop-Damaging Temperatures Increase Suicide Rates in India. Proceedings of the National Academy of Sciences, 114, 8746-8751. https://doi.org/10.1073/pnas.1701354114

[15] Thimmaiah, R., Poreddi, V., Ramu, R., Selvi, S. and Math, S. (2016) Influence of Religion on Attitude towards Suicide. Journal of Religion and Health, 55, 2039-2052. https://doi.org/10.1007/s10943-016-0213-Z

[16] Norko, M.A., Freeman, D., Phillips, J., Hunter, W., Lewis, R. and Viswanathan, R. (2017) Can Religion Protect Against Suicide? The Journal of Nervous and Mental Disease, 205, 9-14. https://doi.org/10.1097/NMD.0000000000000615

[17] Akbari, A., Haghdoost, A.A., Nakhaee, N., Bahramnejad, A., Baneshi, M.R. and Zolala, F. (2015) Risk and Protective Factor for Suicide Attempt in Iran: A Matched Case-Control Study. Archives of Iranian Medicine, 18, 747-752.

[18] Lester, D. (2006) Suicide and Islam. Archives of Suicide Research, 10, 77-97. https://doi.org/10.1080/13811110500318489

[19] Neeleman, J. and Lewis, G. (1999) Suicide, Religion, and Socioeconomic Conditions. An Ecological Study in 26 Countries, 1990. Journal of Epidemiology \& Community Health, 53, 204-210. https://doi.org/10.1136/jech.53.4.204

[20] VanderWeele, T.J., Li, S., Tsai, A.C. and Kawachi, I. (2016) Association between Religious Service Attendance and Lower Suicide Rates among US Women. JAMA 
Psychiatry, 73, 845-851. https://doi.org/10.1001/jamapsychiatry.2016.1243

[21] Kostenuik, M. and Ratnapalan, M. (2010) Approach to Adolescent Suicide Prevention. Canadian Family Physician, 56, 755-760.

[22] NIMH (2019) Suicide Prevention. National Institute of Mental Health, Bethesda. https://www.nimh.nih.gov/health/topics/suicide-prevention

[23] Conwell, Y., Duberstein, P.R. and Caine, E.D. (2002) Risk Factors for Suicide in Later Life. Society of Biological Psychiatry, 52, 193-204.

https://doi.org/10.1016/S0006-3223(02)01347-1

[24] Harford, T.A., Yi, H.-Y. and Grant, B.F. (2014) Associations between Childhood Abuse and Interpersonal Aggression and Suicide Attempt among U.S. Adults in a National Study. Child Abuse \& Neglect, 38, 1389-1398. https://doi.org/10.1016/j.chiabu.2014.02.011

[25] Trout, D.L. (1980) The Role of Social Isolation in Suicide. Suicide and Life Threatening Behavior, 10, 10-23. https://doi.org/10.1111/j.1943-278X.1980.tb00693.x

[26] Bhar, S., Ghahramanlou-Holloway, M., Brown, G. and Beck, A.T. (2008) Self-Esteem and Suicide Ideation in Psychiatric Outpatients. Suicide and Life-Threatening Behavior, 38, 511-516. https://doi.org/10.1521/suli.2008.38.5.511

[27] Sharaf, A.Y., Thompson, E.A. and Walsh, E. (2009) Protective Effects of Self-Esteem and Family Support on Suicide Risk Behaviors among At-Risk Adolescents. Journal of Child and Adolescent Psychiatric Nursing, 22, 160-168.

https://doi.org/10.1111/j.1744-6171.2009.00194.x

[28] Gvion, Y. and Apter, A. (2012) Suicide and Suicidal Behavior. Public Health Reviews, 34, 1-12. https://doi.org/10.1007/BF03391677

[29] Fuller-Thomson, E., Baker, T.M. and Brennenstuhl, S. (2012) Evidence Supporting an Independent Association between Childhood Physical Abuse and Lifetime Suicidal Ideation. Suicide and Life-Threatening Behavior, 42, 279-291. https://doi.org/10.1111/j.1943-278X.2012.00089.x

[30] Ineichen, B. (2008) Suicide and Attempted Suicide among South Asians in England: Who Is at Risk? Mental Health in Family Medicine, 5, 135-138.

https://www.ncbi.nlm.nih.gov/pmc/articles/PMC2777567

[31] CDC (2008) Promoting Individual, Family, and Community Connectedness to Prevent Suicidal Behavior. Strategic Direction for the Prevention of Suicidal Behavior. 2-10.

https://www.cdc.gov/ViolencePrevention/pdf/Suicide Strategic Direction Full Ver sion-a.pdf

[32] Dervic, K., Oquendo, M.A., Grunebaum, M.F., Ellis, S., Burke, A.K. and Mann, J.J. (2004) Religious Affiliation and Suicide Attempt. American Journal of Psychiatry, 161, 2303-2308. https://doi.org/10.1176/appi.ajp.161.12.2303

[33] Malone, K.M., Oquendo, M.A., Haas, G.L., Ellis, S.P., Li, S. and Mann, J.J. (2000) Protective Factors against Suicidal Acts in Major Depression: Reasons for Living. American Journal of Psychiatry, 157, 1084-1088.

https://doi.org/10.1176/appi.ajp.157.7.1084

[34] Hirsch, J.K., Duberstein, P.R., Conner, K.R., Heisel, M.J., Beckman, A., Franus, N. and Conwell, Y. (2006) Future Orientation and Suicide Ideation and Attempts in Depressed Adults Ages 50 and Over. The American Journal of Geriatric Psychiatry, 14, 752-757. https://doi.org/10.1097/01.JGP.0000209219.06017.62

[35] Niederkrotenthaler, T., Reidenberg, D.J., Till, B. and Gould, M.S. (2014) Increasing Help-Seeking and Referrals for Individuals at Risk for Suicide by Decreasing Stig- 
ma: The Role of Mass Media. American Journal of Preventive Medicine, 47, S235-S243. https://doi.org/10.1016/j.amepre.2014.06.010

[36] World Health Organization (2012) Public Health Action for the Prevention of Suicide: A Framework.

[37] Koenig, H.G., Larson, D.B. and Larson, S.S. (2001) Religion and Coping with Serious Medical Illness. Annals of Pharmacotherapy, 35, 352-359. https://doi.org/10.1345/aph.10215

[38] Koenig, H.G., McCullough, M.E. and Larson, D.B. (2001) Handbook of Religion and Health. Oxford University Press, Oxford. https://doi.org/10.1093/acprof:oso/9780195118667.001.0001

[39] Nelson, C.J., Rosenfeld, B., Breitbart, W. and Galietta, M. (2002) Spirituality, Religion, and Depression in the Terminally Ill. Psychosomatics, 43, 213-220. https://doi.org/10.1176/appi.psy.43.3.213

[40] Wu, A., Wang, J.-Y. and Jia, C.-X. (2015) Religion and Completed Suicide: A Meta-Analysis. PLoS ONE, 10, e0131715. https://doi.org/10.1371/journal.pone.0131715

[41] Rushing, N.C., Corsentino, E., Hames, J.L. and Sachs-Ericsson, N. (2013) The Relationship of Religious Involvement Indicators and Social Support to Current and Past Suicidality among Depressed Older Adults. Aging \& Mental Health, 17, 366-374. https://doi.org/10.1080/13607863.2012.738414

[42] Al-Albani, M. (1987) The Selected Collections of Authenticated Hadith "Sahih Al-Jami A-Sghir. Al-Shawish, Z., Ed. 3rd Edition, The Islamic Bureau, Beirut.

[43] Al-Naysaburi, M.I.-H.-Q. (1955) Sahih Muslim. In: Abdul-Baqi, M.F., Ed., Sahih Muslim-Al-Musnad Al-Sahih, Dar Ihiya'a Alkutub Al-Arabiyya, Cairo, 2608.

[44] Daradkeh, T. (1989) Suicide in Jordan 1980-1985. Acta Psychiatrica Scandinavica, 79, 241-244. https://doi.org/10.1111/j.1600-0447.1989.tb10252.x

[45] Sarfraz, A. and Castle, D. (2002) A Muslim Suicide. Australasian Psychiatry, 10, 48-50. https://doi.org/10.1046/j.1440-1665.2002.00392.x

[46] Al-Bukhari, M.B. (1979) Sahih Bukhari. In: Al-Khatib, M.-D., Ed., Jami Al-Musnad As-Sahih, Salafi Publication Library, Cairo, 5754.

[47] Al-Albani, M. (1988) The Selected Collections of Authenticated Hadith "Sahih Al-Jami A-Sghir”. Al-Shawish, Z., Ed. The Islamic Bureau, Beirut.

[48] Park, C. (2005) Handbook of the Psychology of Religion and Spirituality. The Guilford Press, New York.

[49] Issa, M.A. (2019) Suicide Motives and Treatment in the Light of the Prophetic Sunnah, 1251-1340.

[50] Gearing, R.E. and Lizardi, D. (2008) Religion and Suicide. Journal of Religion and Health, 48, 332-341. https://doi.org/10.1007/s10943-008-9181-2

[51] Shah, A. and Chandia, M. (2010) The Relationship between Suicide and Islam: A Cross-National Study. Journal of Injury and Violence Research, 2, 93-97. https://doi.org/10.5249/jivr.v2i2.60

[52] Hicks, M.H.-R. and Bhugra, D. (2003) Perceived Causes of Suicide Attempts by U.K. South Asian Women. American Journal of Orthopsychiatry, 73, 455-462. https://doi.org/10.1037/0002-9432.73.4.455

[53] van Bergen, D.D., van Balkom, A.J., Smit, J.H. and Saharso, S. (2011) "I Felt So Hurt and Lonely": Suicidal Behavior in South Asian-Surinamese, Turkish, and Moroccan Women in the Netherlands. Transcultural Psychiatry, 49, 69-86.

https://doi.org/10.1177/1363461511427353 
[54] Chan, L.F., Maniam, T. and Shamsul, A.S. (2011) Suicide Attempts among Depressed Inpatients with Depressive Disorder in a Malaysian Sample. Crisis, 32, 283-287. https://doi.org/10.1027/0227-5910/a000088

[55] El-Sayed, A.M., Tracy, M., Scarborough, P. and Galea, S. (2011) Suicide among Arab-Americans. PLoS ONE, 6, e14704.

https://doi.org/10.1371/journal.pone.0014704

[56] Altindag, A., Ozkan, M. and Oto, R. (2005) Suicide in Batman, Southeastern Turkey. Suicide and Life-Threatening Behavior, 35, 478-482.

https://doi.org/10.1521/suli.2005.35.4.478 